\title{
A revised dual-pathway model for disordered eating: A longitudinal study
}

\author{
Jamie-Lee Pennesi, ${ }^{*}$ Tracey D Wade \\ From 2015 ANZAED Conference: Riding the Waves to Recovery \\ Surfers Paradise, Australia. 21-22 August 2015
}

\section{Background}

To date, relatively few researchers have developed and tested integrative etiological models for the full range of disordered eating behaviours, both clinical and subclinical. In addition, much of the research conducted in this area has been correlational; few studies have investigated disordered eating growth over time. Accordingly, the current research aims to replicate and extend the dual pathway model of bulimic pathology (Stice, 2001), which has helped inform the gold standard of prevention approaches for eating disorders among adult women, to the full range of disordered eating behaviours. This research will also examine a revised model which incorporates temperament: perfectionism, self-efficacy, emotion regulation, which has shown to be predominant in the development and maintenance of eating pathology.

\section{Methods}

Females aged 17-25 years were tested at baseline $(\mathrm{N}=181)$, and at 6 -month $(\mathrm{N}=67)$ and 12-month follow-up (in progress). Final follow-up data for this sample will be available for analyses by the end of June 2015 .

\section{Results}

Preliminary analyses from Time 1 (baseline) suggest a promising line of enquiry with the addition of temperament (e.g., perfectionism) within the dual pathway model. Findings from Time 1, Time 2, and Time 3 will be presented.

\section{Conclusion}

This study will add important insights to the eating disorder prevention literature and help to inform the development of approaches to prevention.

* Correspondence: jamie-lee.pennesi@flinders.edu.au

Flinders University, Bedford Park, Australia

C 2015 Pennesi and Wade This is an Open Access article distributed under the terms of the Creative Commons Attribution License (http://creativecommons.org/licenses/by/4.0), which permits unrestricted use, distribution, and reproduction in any medium, provided the original work is properly cited. The Creative Commons Public Domain Dedication waiver (http://creativecommons.org/ publicdomain/zero/1.0/) applies to the data made available in this article, unless otherwise stated.
doi:10.1186/2050-2974-3-S1-O56

Cite this article as: Pennesi and Wade: A revised dual-pathway model for disordered eating: A longitudinal study. Journal of Eating Disorders 2015 3(Suppl 1):056.
Submit your next manuscript to BioMed Central and take full advantage of:

- Convenient online submission

- Thorough peer review

- No space constraints or color figure charges

- Immediate publication on acceptance

- Inclusion in PubMed, CAS, Scopus and Google Scholar

- Research which is freely available for redistribution \\ () Biomed Central}

